\title{
USE OF SLUDGE FROM KRAFT MILL WASTEWATER TREATMENT AS IMPROVER OF VOLCANIC SOILS: EFFECT ON SOIL BIOLOGICAL PARAMETERS
}

\author{
F. Gallardo ${ }^{1,3}$, C. Bravo ${ }^{1}$, G. Briceño ${ }^{3}$, M.C Diez ${ }^{2,3}$ \\ ${ }^{1}$ Chemical Science Department, ${ }^{2}$ Chemical Engineering Department, ${ }^{3}$ Scientific and \\ Technological Bioresource Nucleus, Universidad de La Frontera, P.O. Box 54-D, Temuco, Chile. \\ *Corresponding author: fgallar@ufro.cl
}

\begin{abstract}
Sludge from kraft mill wastewater treatment was applied on two soils derived from volcanic ashes and, the effect on biological parameters of the soils was evaluated. The soils used in this study were an Andisol belonging of Gorbea Series and an Ultisol belonging of Collipulli Series. The sludge was added at rates of $0,10,20,30$ and $50 \mathrm{t}$ $\mathrm{ha}^{-1}$. Previously, germination of red clover (Trifolium pratense), white clover (Trifolium repens), alfalfa (Medicago sativa) and ryegrass (Lolium perenne) was tested to assess phytotoxicity of the sludge. The different soil-sludge mixtures were incubated at controlled temperature for 60 days and microbial respiration, microbial biomass carbon, fluorescein diacetate hydrolysis and acid phosphatase activity were evaluated throughout the incubation time. All biological parameters evaluated were sensitive enough to shown the effect of sewage sludge application on soil microorganisms. The sludge application at different rates increased significantly $(P<0.05)$ the microbial activity and enzymatic activity of the sludge amended soils. The maximum levels of activity were observed between 15 and 30 days after sludge application in both Gorbea soil and Collipulli soil, obtaining the highest values when were applied between 30 and $50 \mathrm{t} \mathrm{ha}^{-1}$. The results of this study suggest that sludge from kraft mill wastewater treatment may have potential as a beneficial soil amendment for improving biological properties of the soils.
\end{abstract}

Keywords: volcanic soils, kraft mill sludge, phytotoxicity, biological parameters

\section{INTRODUCTION}

The application of sludge from pulp and paper mill wastewater treatment improves physical, chemical and biological properties of soils, hence vegetable production, and it could be used as a partial replacement of more expensive chemical fertilizers (Zhang et al., 2004; Aravena et al., 2007; Gallardo et al., 2007). The benefic effects of this organic waste on soil properties are explained by the chemical characteristics of the sludge: high organic matter (OM) content, high levels of macro (N, P and $\mathrm{K}$ ) and micronutrients ( $\mathrm{B}, \mathrm{Cu}, \mathrm{Ni}, \mathrm{Zn}, \mathrm{Mn}, \mathrm{S})$, essential to the plant requirements, and low concentrations of trace metals and organic pollutants (Gagnon et al., 2001; Gallardo et al., 2007). Additionally, 
sludge increases water-holding capacity and nutrients retention in the soil, decreases soil acidification, increases plant roots penetration, and improves texture and structure of soils (O'Brien et al., 2002; Aravena et al., 2007; Rato Nunes et al., 2008). Then, sludge from wastewater treatment is an attractive alternative to ameliorate degraded soils.

There is little information published on the application of sludge from kraft mill wastewater treatment into Chilean soils derived from volcanic ashes (Andisols and Ultisols). In Chile, this type of soil represents approximately 3.1 million ha, and presents diverse degrees of erosion. According to a recent study realized and next to be published by the Center of Information of Natural Resources (CIREN), about of $47,000,000$ ha are eroded, representing $60 \%$ of national territory, of these being seriously affected agricultural and productive lands.

The main characteristics of Chilean soils derived from volcanic ashes are acidic $\mathrm{pH}$ (4.7 to 6.5 , with the average of 5.5), high extractable $\mathrm{Al}$ and, high $\mathrm{P}$ fixation which increases when $\mathrm{pH}$ decreases (Mora et al., 2006a). Toxicity produced by aluminum is considered to be one of the most important limiting factors in plant growth in soils with high acidity (Gallardo et al, 1999; Gallardo et al., 2005). On the other hand, phosphorus is an essential nutrient for the metabolism of living organisms. However, in spite of its wide distribution in nature, phosphorus is a limited resource and it is deficient in most soils (Fuentes et al., 2006).

Soil quality can be evaluated quantitatively through physico-chemical and biological parameters. Measurements of biological parameters have been used to indicate changes in soil quality due to long-term treatments and different forms of management (Nannipieri et al., 1995; Alvear et al., 2006; Ros et al., 2006).
However, it is not clear which indicator responds to a specific soil treatment. Therefore, the use of multiple biological and biochemical properties is often suggested. General biochemical properties such as microbial biomass, $\mathrm{CO}_{2}$ evolution from microbial respiration, and hydrolysis of fluorescein diacetate (FDA), which represent an estimation of microbial activity, are general methods to obtain an adequate index of soil fertility (Adam and Duncan, 2001; Sánchez-Monedero et al., 2008), as well as specific biochemical properties such as hydrolytic soil enzymes related to carbon, nitrogen and phosphorous cycles are suggested (Ros et al., 2006). Specifically, phosphatases comprise a broad group of extra-cellular enzymes which catalyze the hydrolysis of both phosphate ester bonds and anhydride bonds. These enzymes release orthophosphate from organic and inorganic compounds, thereby increasing the bioavailable $\mathrm{P}$; hence their behavior can be related to phosphorus levels in the soil, being a good indicator in soils derived from volcanic ashes (Deng and Tabatabai, 1997; Mora et al., 2006b).

In general, the incorporation of organic residues can improve soil condition. The application of sludge from kraft mill wastewater treatment have modified some physical and chemical properties of an Andisol (Aravena et al., 2007; Gallardo et al., 2007), however its effect on some biological properties has not been evaluated. Following the previous research, the aim of this study was to assess the effect of application of different rates of sludge from the kraft mill wastewater treatment on the biological properties of soils derived from volcanic ashes. In our case, we choose global parameters such as microbial respiration, microbial biomass carbon (MBC) and FDA hydrolysis and, specific parameters such as acid phosphatase activity to 
evaluate the effect of the application of kraft mill sludge on two soils of volcanic origin. Previously, the phytotoxicity of sludge before its applying to soils was also evaluated.

\section{MATERIAL AND METHODS}

\section{Soils and sludge}

The soils used in this study were an Andisol belonging to Gorbea Series (Mesic, Typic Hapludands) and an Ultisol belonging to Collipulli Series (Typics Rhodoxeralfs ) (Ciren, 2002), both soils from southern Chile. Soil samples were collected from the surface layer (0-20 $\mathrm{cm})$, air dried, passed through a $2 \mathrm{~mm}$ sieve and stored in plastic bags at $4^{\circ} \mathrm{C}$.

The sludge used in this trial was obtained from an aerated pond that treated bleached kraft mill wastewater and was collected from a landfill after one year disposal. Selected soil properties of both soils and characteristics of the secondary sludge used as soil amendment are summarized in Table 1.

\section{Phytotoxicity assay}

The sludge phytotoxicity was evaluated according to standard methods proposed by Zucconi et al. (1981) and Tiquia (2000). Briefly, a filter paper Whatman $N^{o} 2$ moistened with sludge extract $(1: 10$ $\mathrm{w} / \mathrm{v}$ with deionized water) was placed in sterile Petri dishes. Then, 30 seeds of Trifolium pratense (red clover), Trifolium repens (white clover), Medicago sativa (alfalfa) or Lolium perenne (ryegrass) were added on the filter paper. Deionized water was used as control. Plates were sealed with parafilm to minimize moisture loss and stored for 7 days at $25^{\circ} \mathrm{C}$. At the end of the incubation period, the percentage $(\%)$ of seed germination in sludge extract was calculated in relation to germination obtained in the control test (100\%).

\section{Incubation soil-sludge mixtures}

The equivalent of $0,10,20,30$ and $50 \mathrm{t}$ $\mathrm{ha}^{-1}$ of sludge were applied to Gorbea soil and Collipulli soil and then carefully mixed. Considering that sludge is incorporated into the first $20 \mathrm{~cm}$ of the soil and, according with soil bulk density (Table 1), 0, 5.26, 10.92, 15.78 and 26.30 $\mathrm{g}$ per 1,000 g of Gorbea soil, and 0, 4.24, $8.48,12.72$ and $21.20 \mathrm{~g}$ per $1,000 \mathrm{~g}$ of Collipulli soil were applied. After homogenizing the soil-sludge mixtures, the incubation of each treatment was conducted for 60 days in a growth chamber at constant temperature $(20 \pm 2$ ${ }^{\circ} \mathrm{C}$ ), the humidity was adjusted to $50-60 \%$ of water holding capacity (WHC) and maintained at a constant level throughout the experiment by distilled water addition. Samples of soil and mixture were taken every 15 days for the determination of carbon biomass, FDA hydrolysis and acid phosphatase activity during the incubation period.

\section{Microbial parameters}

Cumulated microbial respiration of the soils and soil-sludge mixtures were estimated by measuring $\mathrm{CO}_{2}$ evolution (Alef, 1995), beginning after 15 days of sludge application in soils. Portions of fresh moist soil and soil-sludge mixtures $(50 \mathrm{~g})$ were placed into $1 \mathrm{~L}$ capacity sealed flasks and incubated for 20 days at $25^{\circ} \mathrm{C}$.

The $\mathrm{CO}_{2}$ production during the incubation was trapped in $10 \mathrm{~mL}$ of $\mathrm{NaOH} 0.5 \mathrm{M}$ placed in each flask. A vial with distilled water was used to keep the humidity constant throughout the experiment. The excess alkali was back titrated with a solution of $0.1 \mathrm{M} \mathrm{HCl}$ after 
Table 1. Chemical Characterization of Gorbea soil, Collipulli soil and sludge at the beginning of the experiment.

\begin{tabular}{|c|c|c|c|}
\hline Parameter & Gorbea soil & Collipulli soil & Sludge \\
\hline Soil bulk density $\left(\mathrm{g} \mathrm{cm}^{-3}\right)$ & 0.95 & 1.18 & - \\
\hline Nitrogen $\left(\mathrm{mg} \mathrm{kg}^{-1}\right)$ & $21.96 \pm 0.59$ & $18.19 \pm 1.57$ & $586.2 \pm 6.55$ \\
\hline Phosphorus (mg kg ${ }^{-1}$ ) & $11.53 \pm 0.99$ & $10.20 \pm 0.99$ & $313.00 \pm 19.16$ \\
\hline $\mathrm{pH}\left(\mathrm{H}_{2} \mathrm{O}\right)$ & $4.76 \pm 0.02$ & $5.62 \pm 0.02$ & $6.97 \pm 0.02$ \\
\hline Organic matter (\%) & $15.05 \pm 0.13$ & $16.37 \pm 0.03$ & $76.1 \pm 0.96$ \\
\hline Potassium $\left(\mathrm{cmol}(+) \mathrm{kg}^{-1}\right)$ & $0.16 \pm 0.01$ & $0.39 \pm 0.02$ & $3.62 \pm 0.31$ \\
\hline Sodium $\left(\mathrm{cmol}(+) \mathrm{kg}^{-1}\right)$ & $0.07 \pm 0.001$ & $0.07 \pm 0.01$ & $41.55 \pm 1.67$ \\
\hline Calcium $\left(\operatorname{cmol}(+) \mathrm{kg}^{-1}\right)$ & $0.48 \pm 0.02$ & $5.52 \pm 0.08$ & $27.95 \pm 1.63$ \\
\hline Magnesium $\left(\mathrm{cmol}(+) \mathrm{kg}^{-1}\right)$ & $0.48 \pm 0.01$ & $1.27 \pm 0.09$ & $13.68 \pm 0.39$ \\
\hline Aluminum $\left(\mathrm{cmol}(+) \mathrm{kg}^{-1}\right)$ & $0.94 \pm 0.01$ & $0.13 \pm 0.01$ & $0.03 \pm 0.001$ \\
\hline Total Bases $\left(\mathrm{cmol}(+) \mathrm{kg}^{-1}\right)$ & $1.13 \pm 0.03$ & $7.19 \pm 0.20$ & $86.80 \pm 4.00$ \\
\hline CICE $\left(\operatorname{cmol}(+) \mathrm{kg}^{-1}\right)$ & $2.07 \pm 0.04$ & $7.32 \pm 0.21$ & $86.83 \pm 4.00$ \\
\hline Al saturation (\%) & 45.41 & 1.72 & 0.04 \\
\hline Zinc $\left(\mathrm{mg} \mathrm{kg}^{-1}\right)$ & $0.30 \pm 0.02$ & $0.24 \pm 0.01$ & $376.30 \pm 1.31$ \\
\hline Manganese $\left(\mathrm{mg} \mathrm{kg}^{-1}\right)$ & $4.95 \pm 0.16$ & $25.09 \pm 2.03$ & $111.15 \pm 1.97$ \\
\hline Copper (mg kg $\left.{ }^{-1}\right)$ & $1.17 \pm 0.04$ & $5.60 \pm 0.17$ & $5.04 \pm 0.05$ \\
\hline Iron $\left(\mathrm{mg} \mathrm{kg}^{-1}\right)$ & $34.96 \pm 1.46$ & $31.12 \pm 1.32$ & $18.47 \pm 0.11$ \\
\hline Conductivity ( $\mathrm{dS} \mathrm{m}^{-1}$ ) & ---------- & ----------- & $16.6 \pm 0.76$ \\
\hline
\end{tabular}

The average values and the standard error are presented $(n=3)$.

precipitating the carbonate with $1 \mathrm{~mL}$ of $1.5 \mathrm{M} \mathrm{BaCl}_{2}$ solution using phenolphthalein as indicator. The $\mathrm{NaOH}$ solutions were replaced periodically before re-closing the flasks. The data were expressed as mg $\mathrm{CO}_{2}-\mathrm{C} 100 \mathrm{~g}^{-1}$ of soil.

The MBC was determined by the chloroform fumigation-extraction method proposed by Vance et al. (1987). Moist soil and soil-sludge mixture subsamples $(25 \mathrm{~g})$ were fumigated with alcohol-free $\mathrm{CHCl}_{3}$ in a closed vessel for $24 \mathrm{~h}$. The organic carbon content of fumigated and unfumigated (control) treatments was extracted with $0.5 \mathrm{M} \quad \mathrm{K}_{2} \mathrm{SO}_{4}$ and determined by wet combustion of OM treated with a mixture of $0.5 \mathrm{M}$ sodium dicromate and sulfuric acid (Sadzawka et al., 2004). An extraction efficiency coefficient of 0.45 was used to convert organic C to MBC (Vance et al., 1987).

The total microbial activity was determined through FDA hydrolysis according to method proposed by Schnürer and Rosswall (1982). Briefly, $1.5 \mathrm{~g}$ of soil and soil-sludge mixtures were incubated in a $25 \mathrm{~mL}$ flask with 9.9 $\mathrm{mL}$ of sodium phosphate buffer. The reaction was started by addition of $0.1 \mathrm{~mL}$ of FDA solution $\left(1 \mathrm{mg} \mathrm{mL}^{-1}\right)$. After 1 hour of incubation at $25^{\circ} \mathrm{C}$ in an incubation bath, $10 \mathrm{~mL}$ of acetone were quickly added to stop the reaction. Samples were filtrated (Whatman $\mathrm{N}^{\circ} 40$ ) and the absorbance in the supernatant was 
measured at $490 \mathrm{~nm}$. The concentration of the released fluorescein was calculated by a calibration curve with standard quantities of fluorescein and the results were expressed as $\mu \mathrm{g}$ FDA $g^{-1} h^{-1}$.

The acid phosphatase activity was determined according to the method of Tabatabai and Bremner (1969). One $g$ of soil and soil-sludge mixtures were placed in plastic tubes, the reaction started with the application of $p$-nitrophenyl- $\beta$ glucopiranoside, after incubation for 1 hour at $37^{\circ} \mathrm{C}$, the release p-nitrophenol (PNF) by the specific enzyme by spectrophotometer at $400 \mathrm{~nm}$ was measured. The enzyme activity was expressed as $\mu \mathrm{mol}$ PNF $\mathrm{g}^{-1} \mathrm{~h}^{-1}$.

\section{Data analyses}

All the experiments were carried out in triplicate. The data were statistically analyzed by one-way analysis of variance (ANOVA). When statistical differences were observed, means were separated using Tukey's minimum significant difference test $(P<0.05)$.

\section{RESULTS}

\section{Soils and sludge characteristics}

Table 1 shows the physico-chemical characterization of the kraft mill sludge, Gorbea soil and Collipulli soil. The Gorbea soil presents acidity problems $(\mathrm{pH}$ 4.7), and an elevated percentage of aluminum saturation $(45 \%)$ due to aluminum solubilization $\left(\mathrm{Al}^{3+}\right)$ occurs in acid conditions. By contrast, Collipulli soil presents a $\mathrm{pH}$ of 5.6 and consequently lower aluminum saturation percentage $(1.7 \%)$ because, the equilibrium changes to the neutral species of aluminum $\left(\mathrm{Al}(\mathrm{OH})_{3}\right)$ as $\mathrm{pH}$ increases (Mora et al., 2006a).
The levels of $\mathrm{N}\left(22 \mathrm{mg} \mathrm{kg}^{-1}\right), \mathrm{K}(0.16$ cmol(+) $\left.\mathrm{kg}^{-1}\right), \mathrm{Ca}\left(0.48 \mathrm{cmol}(+) \mathrm{kg}^{-1}\right), \mathrm{Mg}$ $\left(0.48 \mathrm{cmol}(+) \mathrm{kg}^{-1}\right)$ and CICE $(2.07$ $\left.\operatorname{cmol}(+) \mathrm{kg}^{-1}\right)$ in Gorbea soil were low compared with Collipulli soil that contains $18.2 \mathrm{mg} \mathrm{kg}^{-1}$ of $\mathrm{N}, 0.39 \mathrm{cmol}(+)$ $\mathrm{kg}^{-1}$ of $\mathrm{K}, 5.5 \mathrm{cmol}(+) \mathrm{kg}^{-1}$ of $\mathrm{Ca}, 1.27$ $\operatorname{cmol}(+) \mathrm{kg}^{-1}$ of $\mathrm{Mg}$ and CICE of 7.32 $\operatorname{cmol}(+) \mathrm{kg}^{-1}$.

Phosphorous and $\mathrm{OM}$ levels were similar in both soils. The sludge presented a high content of OM (76\%), macronutrients $(\mathrm{N}, \mathrm{P}, \mathrm{K}, \mathrm{Ca}$ and $\mathrm{Mg}$ ), and micronutrients $(\mathrm{Mn}, \mathrm{Cu}$ and $\mathrm{Zn})$. On the other hand, the content of $\mathrm{Fe}$ and $\mathrm{Al}$ are lower compared with Gorbea soil and Collipulli soil. According with the sludge characterization, it is expected that its addition to the soils could contribute to an improvement in the characteristics of this soil and therefore to its fertility. However, the high levels of $\mathrm{Zn}$ and Mn must be taken account because these elements are considered to be toxic for seeds germination and soil microorganisms.

\section{Phytotoxicity assay}

The phytotoxicity of the sludge before its application to soils on four vegetable species was evaluated and the germination index (GI) was calculated (Table 2).

The GI is commonly used as an indicator of salinity or the presence of toxic compounds, such as polyphenols, in stabilized organic waste (Zucconi et al., 1981). Chilean normative (NCh 2880. Of 2004) recommends a GI upper $80 \%$ using sensitive radish species as indicators of toxic compounds in sludge (INN, 2004). According to Zucconi et al. (1981) a GI lower than $50 \%$ shows the presence of high toxicity compounds, a GI between $50-80 \%$ shows the presence of moderate toxicity compounds and GI upper at $80 \%$ shows a nontoxic sludge. 
Table 2. Seed germination (\%) of red clover, white clover, alfalfa and ryegrass after exposure at sludge extract in relation at seed germination in deionized water (control).

\begin{tabular}{lc}
\hline Plant specie & Germination index (\%) \\
\hline Red clover & $133 \pm 5.2$ \\
White clover & $76 \pm 10.5$ \\
Alfalfa & $145 \pm 14.7$ \\
Ryegrass & $43 \pm 3.2$ \\
\hline
\end{tabular}

The average values and the standard deviation are presented $(n=3)$

Our results showed high germination rate for red clover (133\% of emergence) and alfalfa (145\% of emergence), even higher than control germination, indicating non phytotoxic effect of the sludge for these crops according with NCh 2880 Of 2004. In contrast, the rate of seed germination for white clover (76\% of emergence) and ryegrass $(43 \%$ of emergence) was affected negatively with sludge extract. The results can be explained for high salinity and therefore the high electrical conductivity $\left(16.6 \mathrm{dS} \mathrm{m}^{-1}\right)$ of the sludge is higher than the value established by Chilean Normative $\left(<8 \mathrm{dS} \mathrm{m} \mathrm{m}^{-1}\right)$ for organic wastes. A high conductivity affects physiologically the plants, specifically electrical conductivity can influence the water relations of the media thereby influencing germination (O'Brien et al., 2002).

On the other hand, high $\mathrm{Zn}(376 \mathrm{mg}$ $\left.\mathrm{kg}^{-1}\right)$ and $\mathrm{Mn}\left(111 \mathrm{mg} \mathrm{kg}^{-1}\right)$ concentration into kraft mill sludge (Table 1) could cause inhibition on germination of these seeds. Considering the previous facts, it is important to know the toxicity degree of kraft mill sludge alone for each crop, to establish the better sludge-soil dosage to minimizing the inhibitory effect of the amendment on seed germination and soil productivity.

\section{Microbial respiration}

$\mathrm{CO}_{2}$ production was evaluated for sludge and for different soil-sludge mixtures. The cumulative $\mathrm{CO}_{2}$ after 20 days of sludge application in both soils are shown in Table 3. The microbial respiration of the sludge $\left(1,873 \mathrm{mg} \mathrm{CO}_{2}-\mathrm{C} 100 \mathrm{~g}^{-1}\right)$ was 28 times and 44 times higher than observed in Gorbea soil and Collipulli soil, respectively. The respiration of the sludge is equivalent at a respiration rate of 1.23 $\mathrm{mg} \mathrm{C}-\mathrm{CO}_{2} \mathrm{~g}^{-1} \mathrm{~d}^{-1}$, and was below the limit established by NCh 2880 Of 2004 ( $8 \mathrm{mg}$ $\mathrm{C}-\mathrm{CO}_{2} \mathrm{~g}^{-1} \mathrm{~d}^{-1}$ ) indicating that sludge is stabilized. Application of growing rates of sludge increased the soil microbial respiration in both Gorbea and Collipulli soils. For Collipulli soil, the respiration increased as the sludge application was raised, obtaining a $\mathrm{CO}_{2}$ production $80 \%$ higher, compared with unamended Collipulli soil, when $50 \mathrm{t} \mathrm{ha}^{-1}$ of sludge was added. The highest respiration activity (118 mg CO $\mathrm{CO}_{2}-\mathrm{C} 100 \mathrm{~g}^{-1}$ ) was observed for Gorbea soil, specifically when 30 and $50 \mathrm{t} \mathrm{ha}^{-1}$ were added. The $\mathrm{CO}_{2}$ evolution was about $80 \%$ higher than that observed for unamended Gorbea soil, except when $10 \mathrm{t} \mathrm{ha}^{-1}$ of sludge was added, being significantly $(\mathrm{P}<0.05)$ lower than the unamended soil.

The addition of sludge increased the $\mathrm{CO}_{2}$ production of both soils, increasing almost two times the respiration activity when $50 \mathrm{t} \mathrm{ha}^{-1}$ were applied, in respect to the unamended soils. This increment is associated with large amount of easily available carbon, nitrogen and phosphorous sources of the sludge (Table 1) that would have triggered microbial activity. A similar response between soils after sludge application (50 $\left.\mathrm{t} \mathrm{ha}^{-1}\right)$ was observed, in spite of the acidic conditions of Gorbea soil ( $\mathrm{pH}$ of 4.7) that influence the aluminum saturation (Gallardo et al., 1999) and the phosphorous availability, hence, the biological activity of the soil. 
Table 3. Cumulated $\mathrm{CO}_{2}$ production $\left(\mathrm{mg} \mathrm{CO}_{2}-\mathrm{C} 100 \mathrm{~g}^{-1}\right.$ ) after 20 days of incubation. Amended Collipulli soil and amended Gorbea soil with sludge at rates of $0,10,20,30$ and $50 \mathrm{tha}^{-1}$.

\begin{tabular}{lccccc}
\hline Sample & \multicolumn{5}{c}{ Rate of sludge $\left(\mathbf{t ~ h a}^{-\mathbf{1}}\right)$} \\
\cline { 2 - 6 } & $\mathbf{0}$ & $\mathbf{1 0}$ & $\mathbf{2 0}$ & $\mathbf{3 0}$ & $\mathbf{5 0}$ \\
\hline Sludge & $1,873^{*}$ & & & & \\
Gorbea soils & $65.83(1.20) \mathrm{b}$ & $49.66(1.20) \mathrm{c}$ & $63.65(1.21) \mathrm{b}$ & $114.77(1.25) \mathrm{a}$ & $117.85(1.85) \mathrm{a}$ \\
Collipulli soil & $42.60(0.01) \mathrm{c}$ & $45.37(0.86) \mathrm{c}$ & $51.02(0.86) \mathrm{b}$ & $70.83(0.87) \mathrm{a}$ & $76.28(0.87) \mathrm{a}$ \\
\hline
\end{tabular}

This value was no considered in statistic analysis. Different letters indicate significantly different values of each treatment, in a same line, ANOVA with Tukey test, $(P<0.05)$. The average values and the standard deviation are presented $(n=3)$.

Generally, the sludge application leads to a increase of OM in soil (Rato Nunes et al., 2008) due to contribution of stable and soluble OM, both characterized by increase of soil microbial mineralization (Gagnon et al., 2001). According to studies carried out by Gallardo et al. (2009a) an increase of soil OM have been observed for both Collipulli and Gorbea soils after sludge application (30 $\left.\mathrm{t} \mathrm{ha}^{-1}\right)$, explaining the benefic effect of sludge on soil microbial activity observed through this study.

\section{Microbial biomass carbon}

The MBC is considered as a representative method to estimate the whole soil functional entity and moreover to play an important role in nutrient cycling and OM transformation (Goyal et al, 1999; Hojati and Nourbakhsh, 2006). Increasing rates of sludge application raised MBC (Figure $1 \mathrm{~A}, \mathrm{~B}$ ) in both sludge-amended Gorbea and Collipulli soils. The MBC in Gorbea soil increased with the increment of sludge application, and the higher level $\left(12,000 \mathrm{mg} \mathrm{kg}^{-1}\right)$ was obtained after 15 days of incubation with the application of $50 \mathrm{t} \mathrm{ha}^{-1}$ of sludge. For Collipulli soil, the applications of sludge increased the MBC especially when 30 and $50 \mathrm{t} \mathrm{ha}^{-1}$ of sludge were applied, this response was observed throughout the whole incubation period (0-60 days). The highest MBC values for Collipulli soils were observed after 15 days of sludge application, with level of about 7,000 mg $\mathrm{kg}^{-1}$ of MBC for Collipulli soil with $50 \mathrm{t}$ $\mathrm{ha}^{-1}$ of sludge application. After 45 days of incubation, the MBC decreased in both amended and unamended Collipulli soil. However, the values of $\mathrm{MBC}$ in amended soils were higher than in unamended soils (Figure 1B). The MBC in Gorbea soil (Figure 1A) amended with sludge was significantly higher ( 2 or more times) than that observed for Collipulli soil $(P<0.05)$ (Figure 1B).

Soil microbial biomass is a small but labile component of soil OM. Soil microbial biomass and biological activities are frequently used as an indicator of changes in soil resulting from soil management and environmental stresses in agricultural ecosystems. Previous results obtained by Gallardo et al. (2007) and Saravia (2008) indicate that kraft mill sludge application increase the input of OM, and the availability of macronutrients and micronutrients. The effect of sludge application on chemical properties would be directly associated with the improving of biological 

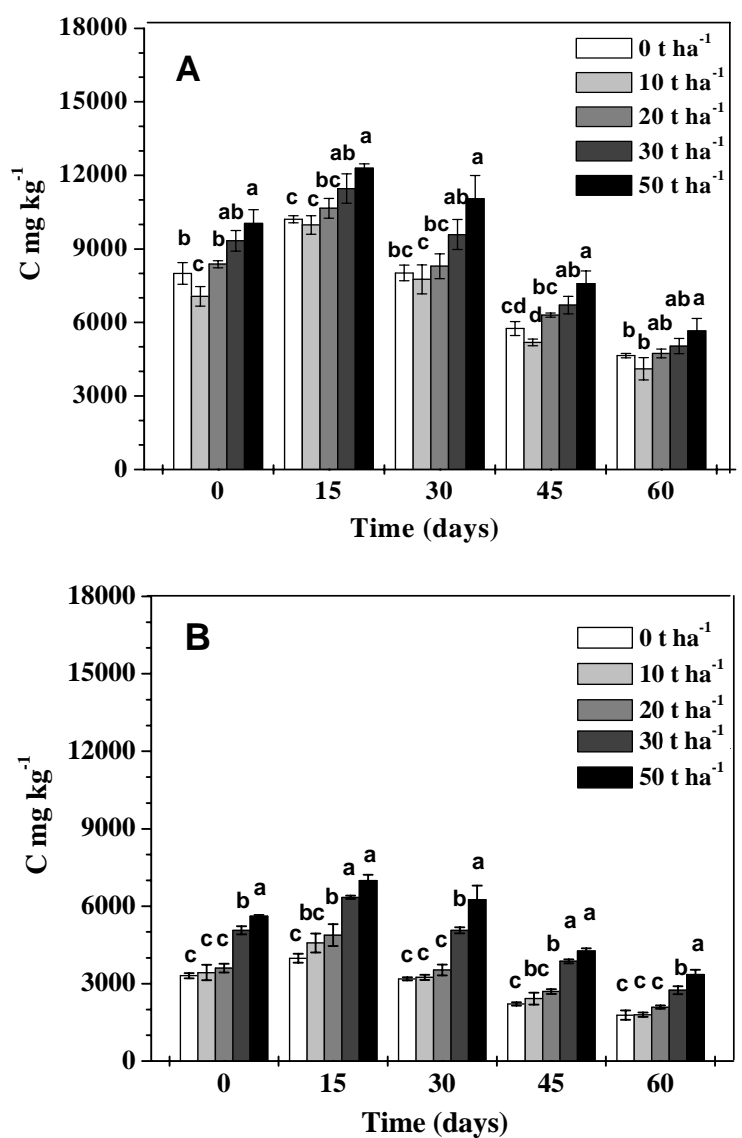

Figure 1. Microbial biomass carbon (MBC) in amended Gorbea soil (A) and amended Collipulli soil (B) with sludge at rates of $0,10,20,30$ and $50 \mathrm{t} \mathrm{ha}^{-1}$, during 60 days of incubation. The average values and the standard error are presented $(n=3)$.

properties, vital for the nutrient turnover and long-term productivity of the studied soils derived from volcanic ashes.

The sludge has high contents of nitrogen, phosphorous and OM (Table 1) increasing the global microbial activity of the soils as reported by other authors (Goyal et al., 1999; Hojati and Nourbakhsh, 2006; Gallardo et al., 2007). Goyal et al. (1999) studied the influence of inorganic fertilizers and organic amendments on soil OM and soil microbial properties under tropical conditions, they found that MBC carbon increased, compared to the control soil, about 3 times in soil amended with wheat straw and inorganic fertilizers. Hojati and Nourbakhsh (2006) studied the effects of cow manure, sewage sludge (25 and $100 \mathrm{t}$ $\mathrm{ha}^{-1}$ ) and chemical fertilizer (250 kg ha ${ }^{-1}$ ) on $\mathrm{MBC}$ and enzyme activities in a calcareous soil cropped to corn. They found that applications of organic amendment increased soil organic $\mathrm{C}$, total 
$\mathrm{N}$, MBC, soil enzymes and corn yield compared to control and chemical fertilizer treatments. On the other hand, Gallardo et al. (2007) have shown that application of sludge at rates of 25 to $75 \mathrm{t}$ $\mathrm{ha}^{-1}$ increased, soil $\mathrm{pH}$ and decreased the percentage of $\mathrm{Al}$ saturation of $43 \%$ to $4.5 \%$, improving the soil productivity which is verified through the increment of MBC, principally in Gorbea soil amended with 30 and $50 \mathrm{t} \mathrm{ha}^{-1}$ of sludge.

\section{FDA activity}

The FDA activity represents an estimation of microbial activity, showing the global hydrolytic capacity of the soil for microbial decomposition of OM (Adam and Duncan, 2001; Sánchez-Monedero et al., 2008).

The FDA values were significantly different $(P<0.05)$ between the evaluated soils. Gorbea soil (Figure 2A) amended with the sludge was about 1.5 or more times higher than the values obtained in Collipulli soil (Figure 2B). The FDA activity in Gorbea soil increased with the increment of sludge application, and the higher level $\left(180 \mu \mathrm{g}\right.$ FDA g $\left.\mathrm{g}^{-1} \mathrm{~h}^{-1}\right)$ was obtained with the application of $50 \mathrm{t} \mathrm{ha}^{-1}$ of sludge, after 30 days of incubation. Similar to those results of FDA obtained with Gorbea soil throughout the all incubation period (0-60 days), the FDA hydrolysis in sludge-amended Collipulli soil was significantly different $(P<0.05)$ compared to unamended Collipulli soil. High rates of sludge application contribute to increase the FDA reaching the maximum levels 30 days after application of sludge. For this time, the FDA activity was about 4.8 times for Collipulli soil with $50 \mathrm{t} \mathrm{ha}^{-1}$ of sludge application compared to unamended soil. After 45 days of incubation, the FDA values decreased in both amended and unamended Collipulli soil, however, the values of FDA obtained in amended soil were higher than in unamended soil $(P<0.05)$.

The increase of FDA hydrolysis indicates increment in the activity of the microorganisms due to OM contribution, macro and micronutrients, and $\mathrm{pH}$ increment by the sludge application. All these elements are essential for microbial growth and soil activity. Gallardo et al. (2007) established that sludge application at rates of 25 to $75 \mathrm{t} \mathrm{ha}^{-1}$ increases the $\mathrm{OM}, \mathrm{N}$ and $\mathrm{P}$ contents in Gorbea soil amended with kraft mill sludge. The authors showed that $\mathrm{Mn}$ and $\mathrm{Zn}$ presence show no negative effects on biological activities of the soil with these levels of sludge application, while the decrease of $\mathrm{Al}$ saturation and increase of $\mathrm{pH}$ favored the development of soil microorganisms. Similar results have been obtained by Gallardo et al. (2009b) with an Andisol belonging to Freire Series in a field study. On the other hand, Sánchez-Monedero et al. (2008) studied three different composting mixtures at different phases of the composting process in a semi-arid soil for 2 months under laboratory conditions. The authors found that FDA hydrolysis activity was mainly affected by the stabilization degree of the added OM, and it was unaffected by the disturbance caused to soil microflora, as evidenced by $\mathrm{qCO}_{2}$. They concluded that FDA hydrolysis determination could serve as an estimation of the size of the soil microflora in freshly amended soils, despite the disturbance caused by the exogenous OM.

\section{Acid phosphatase}

Acid phosphatase is a specific enzymatic activity involved in cycling of phosphorus in soils. Specifically, its function is the phosphorus mineralization through attack of phosphomonoesterase bond present in soil OM, then its increases the phosphorus availability to microorganisms and plants. 

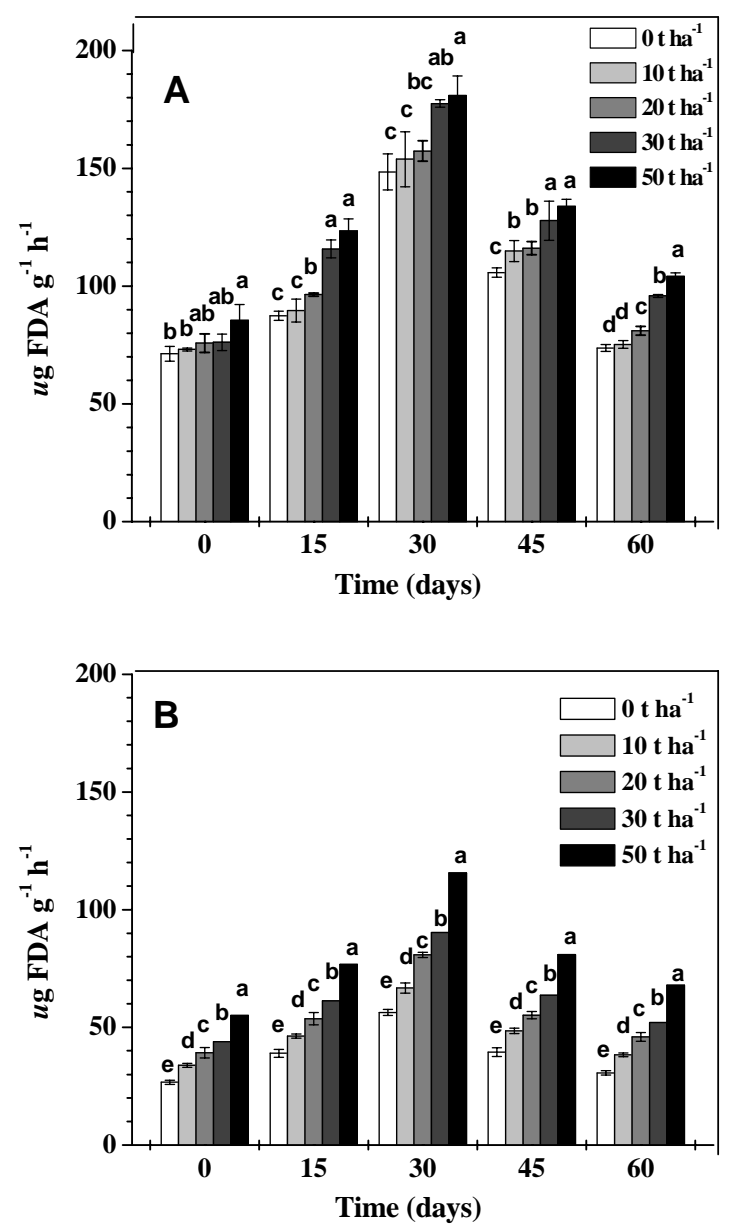

Figure 2. Fluorescein diacetate hydrolisys (FDA) in amended Gorbea soil (A) and amended Collipulli soil (B) with sludge at rates of $0,10,20,30$ and $50 \mathrm{tha}^{-1}$, during 60 days of incubation. The average values and the standard error are presented $(n=3)$.

Our results showed that the sludge application at high rates increases the phosphatase activity in both Gorbea soil and Collipulli soil (Figure 3 A,B) during throughout incubation time (0-60 days), being significantly different $(P<0.05)$ compared to unamended soils. The maximum activity was observed at 30 days of sludge application, and then the phosphatase activity decreased in both amended and unamended Gorbea and
Collipulli soils. However, the values of the enzyme in amended soils were higher than in unamended soils. For Gorbea soil (Figure 3A) the levels of this enzymatic activity was 6 times higher after 30 days of incubation when $50 \mathrm{t} \mathrm{ha}^{-1}$ of sludge was applied, compared to unamended soil. Similarly, the phosphatase activity in Collipulli soil (Figure 3B) the level of this enzymatic activity was 5.5 times higher, compared to unamended soil, after 30 

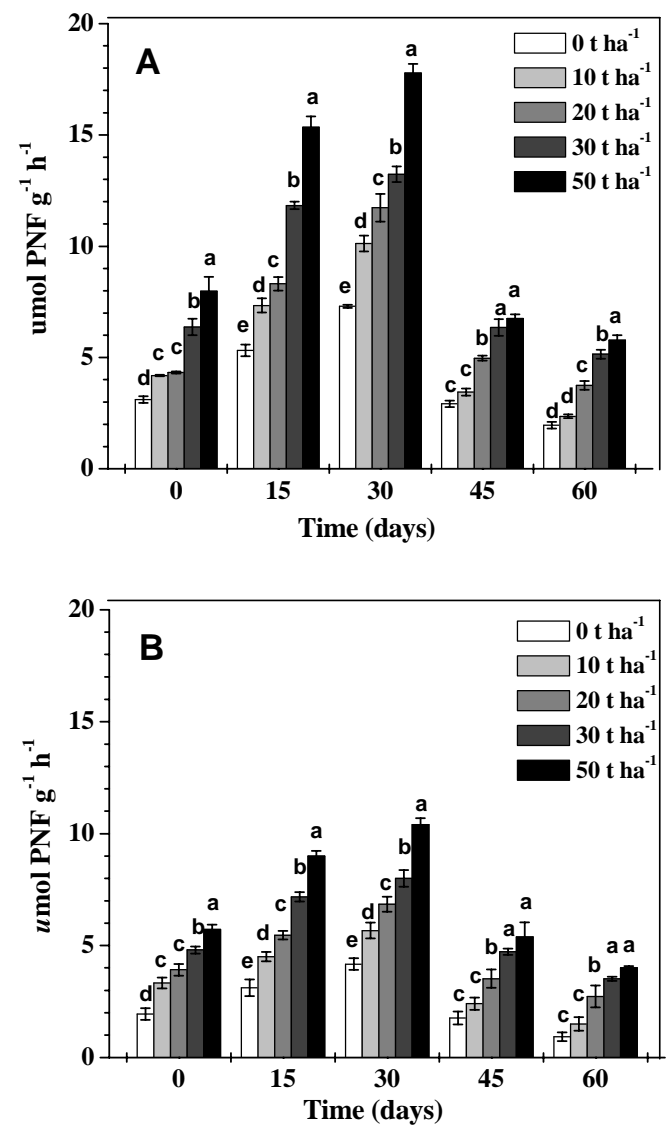

Figure 3. Acid phosphatase activity in amended Gorbea soil (A) and amended Collipulli soil (B) with sludge at rates of $0,10,20,30$ and $50 \mathrm{t}$ ha-1, during 60 days of incubation. The average values and the standard error are presented $(\mathrm{n}=3)$.

days of incubation when $50 \mathrm{t} \mathrm{ha}^{-1}$ of sludge was applied.

The highest acid phosphatase activity observed in sludge-amended Collipulli and Gorbea soils is similar to the results obtained for microbial biomass carbon and FDA hydrolysis, indicating that the sludge addition contributes to increase the overall microbial activity in these soils of volcanic origin. Acidic soils such as used in this study are characterized by present low plant-available phosphorus.
The sludge addition decreases acidity of the soils and consequently decreases $\mathrm{Al}$ saturation and increases available $P$ (Gallardo et al., 2007). An increase of phosphorus availability in soil have been well correlated with the increase of phosphatase activity, being an adequate indicator of microbial activity and of modifications occurred in the soil due to sewage sludge application (Fernandez et al., 2005; Ros et al., 2006). In general, the additions of organic amendment in soils, 
such as sewage sludge, increment the soil microbiological activities (SánchezMonedero et al., 2008). Studies by Gallardo et al. (2007) have shown that the application of sludge from kraft mill sludge increases about 3 times the amount of available $P$ with the addition of $75 t$ $\mathrm{ha}^{-1}$ of sludge to the Gorbea soil which explains the increment of phosphatase activity in sludge-amended soil.

\section{CONCLUSION}

This work showed that MCB, microbial respiration, FDA activity and acid phosphatase activity increased as increasing rates of sludge from kraft mill wastewater treatment were applied to Gorbea and Collipulli soils. The biological parameters exhibited maximum levels between 15 and 30 days after sludge application when were applied between 30 and $50 \mathrm{t} \mathrm{ha}^{-1}$ in both soils, and the positive effect of sludge was observed until the end of the experiment (60 days). In view of our results, we recommended the use of kraft mill sludge as improver of biological properties of soils, previously verifying its level of phytotoxicity and stability to avoid potential hazardous effects over the soil or the plants.

\section{ACKNOWLEDGEMENT}

This research was supported by FONDECYT 1040854 and partially by FONDECYT 1080427 projects.

\section{REFERENCES}

Adam, G., Duncan, H. 2001. Development of a sensitive and rapid method for the measurement of total microbial activity using fluorescein diacetate (FDA) in a range of soils. Soil Biol. Biochem. 33, 943-951.
Alef, K. 1995. Soil Respiration. In: Alef K, Nannipieri P. , editors. Methods in Applied Soil Microbiology and Biochemistry. New York: Academic Press. pp. 214-222.

Alvear, M., Pino, M., Castillo, C., TrasarCepeda, C., Gil-Sotres, F. 2006. Efecto de la cero labranza sobre algunas actividades biológicas en un alfisol del sur de Chile. Rev. Cienc. Suelo Nutr. 6, 38-53.

Aravena, C., Valentin, C., Diez, MC., Mora, ML., Gallardo, F. 2007. Aplicación de lodos de planta de tratamiento de celulosa: efecto en algunas propiedades físicas y químicas de suelos volcánicos. J. Soil Sci. Plant Nutr. 7, 1-14.

CIREN. 2002. Descripciones de suelos. Materiales y símbolos. Estudio agrológico IX región. Publicación CIREN N ${ }^{\circ} 122.360$ pp. Centro de Información de Recursos Naturales (CIREN), Santiago, Chile.

Deng, S., Tabatabai, M. 1997. Effect of tillage and residue management on enzyme activities in soils: III. Phosphatases and arylsulfatase. Biol. Fertil. Soils 24, 141-146.

Fernandes, SA., Bettiol, W., Cerri, C. 2005. Effect of sewage sludge on microbial biomass, basal respiration, metabolic quotient and soil enzymatic activity. Appl. Soil Ecol. 30, 65-77.

Fuentes, B., Bolan, N., Naidu, R., Mora, ML. 2006. Phosphorus in organic waste-soil systems. J.Soil Sc. Plant. Nutr. 6, 64 - 83.

Gagnon, B., Lalande, R., Fahmy, F. 2001. Organic matter and aggregation in a degraded potato soil as affected by raw and composted pulp residue. Biol. Fertil. Soils 34, 441-447.

Gallardo, F., Borie, F., Alvear, M., Von Baer, E. 1999. Evaluation of aluminum tolerant of three barley cultivar by two short-term screening methods and field experiments. Soil Sci. Plant Nutr. 45, 413719. 
Gallardo., F., Pino, M., Alvear, M., Borie, F. 2005. Effect of aluminium on dry matter production and nitrate reductase activity of two wheat genotypes, growing in nutritive solutions. R.C. Suelo Nutr. Veg. 5, 30-36.

Gallardo, F., Mora, ML., Diez, MC. 2007. Kraft mill sludge to improve vegetal production in chilean Andisol. Water Sci. Technol. 55, 31-37.

Gallardo, F., Briceño, G., Saravia, C., Sanhueza, S., Diez, MC. 2009a. Variación de las propiedades físico-químicas de dos suelos por la aplicación repetida de lodo secundario proveniente de la industria de celulosa. Congreso Nacional "suelos: los nuevos desafios” chillán, 24 - 26 de agosto, Chillán, Chile.

Gallardo, F., Briceño, G., Saravia, C., Flores, M J., Sanhueza, S., Diez, MC. 2009b. Biological activity in a soil amended with pull mill sludge: A field study. III International Conference on Environmental, Industrial and Applied Microbiology. BioMicroWorld 2009, 2-4 december, Lisboa, Portugal.

Goyal, S., Chander, K., Mundra, M., Kapoor, K. 1999. Influence of inorganic fertilizers and organic amendments on soil organic matter and soil microbial properties under tropical conditions. Biol. Fertil. Soils 29, 196-200.

Hojati, S., Nourbalhsh, F. 2006. Enzyme activities and microbial biomass carbon in a soil amended with organic and inorganic fertilizer. J. Agron. 5, 563-579.

Instituto Nacional de Normalización (INN). 2004. Norma Chilena de Compost 2880-2004 (NCh 2880-2004), Compost Clasificación y Requisitos, 23 pp.

Mora, ML., Alfaro, MA., Jarvis, SC., Demanet, R., Cartes, P. 2006a. Soil aluminium availability in Andisols of southern Chile and its effect on forage production and animal metabolism. Soil Use Manage. 22, 95-101.
Mora, ML., López, R., Rao, M., Gianfreda, L., Rosas, A. 2006b. Interaction of Phosphatase with a Chilean Andisol Clay in the Presence of Manganese and Molybdenum. 18th World Congress of Soil Science, July 9-15, 2006 - Philadelphia, Pennsylvania, USA.

Nannipieri, P., Lansi, L., Badalucco, J. 1995. La capacità metabolica a la qualità del suolo. Agronomía 29, 312-316.

O'Brien, TA., Herbert, SJ., Barker, AV. 2002. Growth of corn in varying mixtures of paper mill sludge and soil. Commun. Soil Sci. Plant anal. 33, 635-646.

Rato Nunes, J., Cabral, F., López-Piñeiro, A. 2008. Short-term effects on soil properties and wheat production from secondary paper sludge application on two Mediterranean agricultural soils. Bioresour. Technol. 99, 4935-4942.

Ros, M., Pascual, JA., Garcia, C., Hernandez, M., Insam, H. 2006. Hydrolase activities, microbial biomass and bacterial community in a soil after longterm amendment with different composts. Soil Biol. Biochem. 38, 3443-3452.

Sadzawka, A., Grez, R., Mora, ML., Saavedra, N., Carrasco, MA., Rojas, C. 2004. Métodos de análisis recomendados para suelos chilenos, programa de normalización de técnicas y acreditación de laboratorios para los análisis de suelos y tejidos vegetales 6-63.

Sánchez-Monedero, M., Mondini, C., Cayuela, M., Roig, A., Contin, M., De Nobili, M. 2008. Fluorescein diacetate hydrolysis, respiration and microbial biomass in freshly amended soils. Biol. Fertil. Soils 44, 885-890.

Saravia, C. 2008. Evaluación de los efectos de la aplicación sucesiva de lodos provenientes de una planta de tratamientos de riles de la industria de celulosa kraft sobre suelos degradados. Trabajo para optar al título de Ingeniero Ambiental. Universidad de La Frontera, Temuco, Chile, $84 \mathrm{pp}$. 
Schnürer, J., Rosswall, T. 1982. Fluorescein diaceate hydrolysis as a measure of total microbial activity in soil and litter. Appl. Environ. Microbiol. 43, 1256-1261.

Tabatabai, MA., Bremmer, JM. 1969. Use of $p$-nitrophenyl phosphate for assay of soil phosphatase. Soil Biol. Biochem. 1, 301-307.

Tiquia, SM. 2000. Evaluating phytotoxicity of pig manure from the pig on litter system. In: P.R. Warman and B.R. Taylor, Ed., Proceedings of the Internacional Composting Symposium, CBA Press Inc. Truro, NS, pp. 625-647.
Vance, ED., Brookes, PC., Jenkinson, DS. 1987. Microbial biomass measurements in forest soils: the use of chloroform fumigation-incubation method in strongly acid soils. Soil Biol. Biochem. 19, 697-702.

Zhang, S., Wang, S., Shan, X., Mu, H. 2004. Influences of lignin from paper mill sludge on soil properties and metal acumulation in wheat. Biol. Fertil. Soils 40, 237-242.

Zucconi, F., Peram, A., Forte, M., De Bertoldi, M. 1981. Evaluating toxicity of immature compost. Biocycle March-April, 54-56. 